\title{
Current status of therapeutic alternatives for CoVID-19: A narrative review
}

\author{
Abdullah Tarık Aslan', Murat Akova² \\ ${ }^{1}$ Department of Internal Medicine, Gölhisar State Hospital, Burdur, Turkey; \\ ${ }^{2}$ Department of Infectious Diseases and Clinical Microbiology, Hacettepe University Faculty of Medicine, \\ Ankara, Turkey
}

Article received 22 July, 2021; accepted 10 August, 2021

\section{SUMMARY}

Since December 2019, severe acute respiratory syndrome coronavirus-2 (SARS-CoV-2) infection has exploded and led to a global crisis. Currently, the global case numbers topped 200 million, and toll of dead exceeded 4 million around the world. The pathogenesis of coronavirus disease 2019 (COVID-19) is driven by two processes. During the first stage of the infection that lasts around 5-7 days, replication of SARS-CoV-2 occurs. In the second stage, the disease may progress due to an exaggerated inflammatory response leading to tissue damage. Therefore, it is anticipated that antiviral agents would be effective during the early phase of the disease, while immunomodulator agents are likely to be more beneficial in the second stage of COVID-19. This basic concept of disease development led to explore several antiviral and immunomodulator agents for the treatment of COVID-19.

Currently, remdesivir is the only available Food and Drug Administration-approved antiviral agent for the treatment of COVID-19. However, some other agents have been approved by various mechanisms, including Emergency Use Authorizations, Emergency Investigational New Drug applications, compassionate use or expanded access programs. In addition, a variety of repurposed agents that were approved for other indications are being investigated for the treatment of $\mathrm{CO}-$ VID-19 in clinical trials. A myriad of publications including randomized controlled trials (RCTs) are emerging continuously and are accessible as peer-reviewed, pre-print and press release formats. Considering the critical importance of RCTs in generating evidence and providing further guidance on COVID-19 treatment, we herein reviewed only RCTs and meta-analyses.

The discussion includes antiviral agents (hydroxychloroquine, lopinavir/ritonavir, remdesivir, favipiravir and ivermectin) and, various immunomodulatory drugs (corticosteroids, tocilizumab, baricitinib, and IL-1 inhibitors). Other investigational therapies including darunavir/cobicistat, umifenovir, sofosbuvir/daclatasvir, sofobuvir/ledipasvir, ribavirin, nitazoxanide and interferon-based regimens were not evaluated due to insufficient data on the efficacy and safety of these agents.

Key words: SARS-CoV-2, COVID-19, remdesivir, dexamethasone, baricitinib.

\section{INTRODUCTION}

Severe acute respiratory syndrome coronaviSrus 2 (SARS-CoV-2), the causative pathogen of coronavirus disease 2019 (COVID-19), is a highly contagious virus and has led to a global pandem-

$\overline{\text { Corresponding author }}$

Abdullah Tarık Aslan

E-mail: aslanabdullahtarik@gmail.com ic. As of August 03, 2021, the total number of cases has reached up to 200 million worldwide [1]. Although more than $80 \%$ of infected people have a mild illness, around $10 \%$ of individuals require hospital admission due to COVID-19 pneumonia, of whom approximately $10 \%$ will need ICU care [2]. The risk of serious COVID-19 disease is higher in older people ( $\geq 60$ years), those who are residents in a nursing home or a long-term care facility, and those with pre-existing chronic diseases. 
The most common underlying chronic medical conditions are cardiovascular disease, diabetes, and chronic lung diseases. Other high-risk underlying diseases related with severe COVID-19 are cancer, chronic kidney disease, obesity, sickle cell disease, and several other immunocompromising conditions. Transplant recipients and pregnant women also fell in this category [3-7].

Since the beginning of the pandemic, an expanding number of publications have been made as a reflection of scientific endeavor and several great achievements have been witnessed. However, the rapidly emerging literature has made it difficult for healthcare professionals to follow new publications on time while overwhelmed by the COVID-19 pandemic. Therefore, regular and scrutinized appraisal of existing data are needed to stay up to date.

In this review, we aimed to outline the current treatment alternatives for COVID-19. Only articles in English in Pubmed, Google Scholar, Embase, bioRxiv and medRxiv databases and published until May 01, 2021 were reviewed. The definitions used consistently for the classification of COVID-19 severity in contemporary guidelines have been similarly adopted and used $[8,9]$.

\section{ANTIVIRAL DRUGS}

\section{Hydroxychloroquine and chloroquine} with or without azithromycin

Although antiviral activity was supported by in vitro studies, hydroxychloroquine (HCQ) with or without azithromycin was unable to reduce upper or lower airway SARS-CoV-2 viral loads and showed no clinical efficacy in a rhesus macaque model [10, 11].

The results of 9 relevant RCTs were summarized in Table 1. Of these, the RECOVERY trial clearly demonstrated the lack of efficacy in patients treated with HCQ and, consequently, the patient recruitment in the HCQ group was closed on June 5, 2020 [12]. Consistently, the WHO SOLIDARITY trial found similar rate of progression to mechanical ventilation and death in patients receiving HCQ as compared to those treated with local standard of care. Importantly, this RCT also confirmed the findings of the RECOVERY trial by indicating inefficacy of HCQ in terms of 28-day mortality and other secondary outcomes [13]. In another RCT, there were no significant differences between HCQ vs. HCQ plus azithromycin vs. standard care arms in the proportional odds of having a worse score on the seven-point ordinal scale at 15 days [14]. Self et al. confirmed that treatment with HCQ did not significantly improve the clinical status of hospitalized COVID-19 patients at day 14 and, the 28-day mortality rates were similar in HCQ and placebo groups (10.4\% vs. $10.6 \%$; aOR: 1.07; 95\%CI, 0.54-2.09) [15]. In a Chinese RCT, insignificant impact of HCQ, additional to standard of care, on negative conversion of SARS-CoV-2 by 28 days was demonstrated among laboratory confirmed COVID-19 patients [16]. Another RCT from Brazil concluded that combination of azithromycin with standard of care (typically including HCQ at that time in Brazil) did not differentiate clinical status of patients at day 15 according to seven-level ordinal scale [17]. Furthermore, HCQ is not beneficial in pre- and post-exposure prophylaxis of COVID-19, either [18-20].

Mounting evidence showed that HCQ treatment is significantly associated with QT prolongation [14]. It is also well known that HCQ exposure increases the risk of hemolysis in persons with glucose-6-phosphate dehydrogenase (G6PD) deficiency [21, 22]. Drug-drug interactions (DDIs) between HCQ and other drugs metabolized by cytochrome P450 isoenzymes 3A4, 2C8, and 2D6 are frequent [23]. In addition, the use of HCQ with azithromycin may increase the risk of QT prolongation and the risk of DDIs mediated by the cytochrome P450 system.

Two large-scale systematic review and meta-analyses indicated that although HCQ alone was not significantly associated with mortality, HCQ plus azithromycin increased the risk of mortality in patients receiving this combination [24, 25]. Furthermore, the duration of hospital stay was shorter in patients taking standard care in comparison with both HCQ (standard mean difference: 0.57; 95\% CI, 0.20-0.94; $\mathrm{I}^{2}=92 \%$ ) and HCQ plus azithromycin receiving patients (standard mean difference: 0.77; 95\% CI, 0.46-1.08; $\mathrm{I}^{2}=81 \%$ ) [25].

\section{Lopinavir/Ritonavir}

In September 2000, lopinavir/ritonavir was approved by the US Food and Drug Administration (FDA) for the treatment of Human Immunodeficiency Virus. During the replication cycle of SARS-CoV-2, the virus needs to cleavage of polyproteins into an RNA-dependent RNA polymerase and a helicase which is mediated by two 
Table 1 - Selected randomized controlled trials comparing the efficacy of hydroxychloroquine and control group(s).

\begin{tabular}{|c|c|c|c|c|c|}
\hline $\begin{array}{c}\text { Randomized } \\
\text { Controlled Trials }\end{array}$ & Patient Characteristics & Comparison groups & $\begin{array}{l}\text { Number } \\
\text { of patients } \\
\text { included }\end{array}$ & $\begin{array}{c}\text { Primary Outcome } \\
\text { Measure }\end{array}$ & Main results \\
\hline $\begin{array}{l}\text { Recovery Collaborative } \\
\text { Group, Horby P } \\
\text { et al. [12] }\end{array}$ & $\begin{array}{l}\text { Hospitalized patients } \\
\text { with COVID-19 }\end{array}$ & $\begin{array}{l}\text { Hydroxychloroquine } \\
\text { vs. usual care }\end{array}$ & $\begin{array}{c}1561 \\
\text { vs. } 3155\end{array}$ & 28-day mortality & $\begin{array}{l}27 \% \text { vs. } 25 \% \text {; RR: } 1.09 ; \\
95 \% \text { CI, } 0.97-1.23 ; \text { p: } 0.15\end{array}$ \\
\hline $\begin{array}{l}\text { WHO Solidarity Trial, } \\
\text { Pan et al. [13] }\end{array}$ & $\begin{array}{l}\text { Hospitalized patients } \\
\text { with COVID-19 }\end{array}$ & $\begin{array}{l}\text { Hydroxychloroquine } \\
\text { vs. local standard } \\
\text { of care }\end{array}$ & $\begin{array}{c}947 \\
\text { vs. } 906\end{array}$ & 28-day mortality & $\begin{array}{l}10.9 \% \text { vs. } 9.3 \% \text {; RR: } 1.19 \\
95 \% \text { CI, } 0.89-1.59 ; \text { p: } 0.23\end{array}$ \\
\hline Cavalcanti et al. [14] & $\begin{array}{l}\text { Hospitalized patients } \\
\text { with suspected or } \\
\text { confirmed COVID-19 } \\
\text { who were receiving } \\
\text { either no oxygen or } \\
\text { a maximum of } 4 \text { lt/ } \\
\text { min of supplemental } \\
\text { oxygen }\end{array}$ & $\begin{array}{l}\text { Standard care vs. } \\
\text { standard care+ } \\
\text { hydroxychloroquine } \\
\text { vs. standard care+ } \\
\text { hydroxychloroquine+ } \\
\text { azithromycin }\end{array}$ & $\begin{array}{c}229 \\
\text { vs. } 221 \\
\text { vs. } 217\end{array}$ & $\begin{array}{l}\text { Having a higher } \\
\text { score on the seven- } \\
\text { point ordinal scale } \\
\text { at } 15 \text { days }\end{array}$ & $\begin{array}{l}\text { Hydroxychloroquine plus } \\
\text { azithromycin vs. control, } \\
\text { OR: } 0.99 ; 95 \% \text { CI, } 0.57-1.73 \text {; } \\
\text { p: } 1.00 ; \text { hydroxychloroquine } \\
\text { alone vs. control: OR: } 1.21 ; \\
95 \% \text { CI, } 0.69-2.11 ; \text { p: } 1.00 \\
\text { and hydroxychloroquine } \\
\text { plus azithromycin vs. } \\
\text { hydroxychloroquine alone: } \\
\text { OR: } 0.82 ; 95 \% \text { CI, } 0.47-1.43 ; \\
\text { p: } 1.00\end{array}$ \\
\hline Self et al. [15] & $\begin{array}{l}\text { Adults hospitalized } \\
\text { with symptomatic } \\
\text { SARS-CoV-2 infection }\end{array}$ & $\begin{array}{l}\text { Hydroxychloroquine } \\
\text { vs. placebo }\end{array}$ & $\begin{array}{c}242 \\
\text { vs. } 237\end{array}$ & $\begin{array}{l}\text { Clinical status at } 14 \\
\text { days according to } \\
\text { seven-level ordinal } \\
\text { scale }\end{array}$ & $\begin{array}{l}\text { Median IQR score, } 6 \text { (4-7) } \\
\text { vs. } 6 \text { (4-7); aOR: 1.02; } \\
95 \% \text { CI, 0.73- } 1.42\end{array}$ \\
\hline Tang et al. [16] & $\begin{array}{l}\text { Patients admitted } \\
\text { to hospital with } \\
\text { laboratory confirmed } \\
\text { COVID-19 }\end{array}$ & $\begin{array}{l}\text { Hydroxychloroquine+ } \\
\text { standard of care vs. } \\
\text { standard of care }\end{array}$ & $\begin{array}{c}75 \\
\text { vs. } 75\end{array}$ & $\begin{array}{l}\text { Negative conversion } \\
\text { of SARS-CoV-2 by } \\
28 \text { days }\end{array}$ & $\begin{array}{l}85.4 \% \text { vs. } 81.3 \% \text {; } \\
\text { the difference: } 4.1 \% \text {; } \\
95 \% \text { CI, }-10.3 \% \text { to } 18.5 \%\end{array}$ \\
\hline Furtado et al. [17] & $\begin{array}{l}\text { Suspected or } \\
\text { confirmed severe } \\
\text { COVID-19 patients }\end{array}$ & $\begin{array}{l}\text { Azithromycin+ } \\
\text { standard of care vs. } \\
\text { standard of care* }\end{array}$ & $\begin{array}{c}214 \\
\text { vs. } 183\end{array}$ & $\begin{array}{l}\text { Clinical status at } 15 \\
\text { days according to } \\
\text { seven-level ordinal } \\
\text { scale }\end{array}$ & $\begin{array}{l}\text { OR: 1.36; } \\
\text { 95\% CI, 0.94-1.97; p: } 0.11\end{array}$ \\
\hline Boulware et al. [18] & $\begin{array}{l}\text { Adults who had } \\
\text { household or } \\
\text { occupational } \\
\text { exposure to someone } \\
\text { with confirmed } \\
\text { COVID-19 }\end{array}$ & $\begin{array}{l}\text { Hydroxychloroquine } \\
\text { vs. placebo }\end{array}$ & $\begin{array}{c}414 \\
\text { vs. } 407\end{array}$ & $\begin{array}{l}\text { Incidence of } \\
\text { either laboratory- } \\
\text { confirmed } \\
\text { COVID-19 or illness } \\
\text { compatible with } \\
\text { COVID-19 within } \\
14 \text { days }\end{array}$ & $\begin{array}{l}11.8 \% \text { vs. } 14.3 \% \text {; } \\
\text { the difference: }-2.4 \% \text {; } \\
95 \% \text { CI, }-7 \% \text { to } 2.2 \% \text {; } \\
\text { p: } 0.35\end{array}$ \\
\hline Abella et al. [19] & $\begin{array}{l}\text { Health care workers } \\
\text { caring for patients } \\
\text { with COVID-19 }\end{array}$ & $\begin{array}{l}\text { Hydroxychloroquine } \\
\text { vs. placebo }\end{array}$ & $\begin{array}{c}64 \\
\text { vs. } 61\end{array}$ & $\begin{array}{l}\text { Incidence of SARS- } \\
\text { CoV-2 infection as } \\
\text { determined by a } \\
\text { nasopharyngeal } \\
\text { swab during the } 8 \\
\text { weeks of treatment. }\end{array}$ & $\begin{array}{l}6.3 \% \text { vs. } 6.6 \% ; \\
\text { p: }>0.99\end{array}$ \\
\hline Mitjà et al. [20] & $\begin{array}{l}\text { Asymptomatic } \\
\text { contacts of patients } \\
\text { with PCR-confirmed } \\
\text { COVID-19 }\end{array}$ & $\begin{array}{l}\text { Hydroxychloroquine } \\
\text { vs. usual care }\end{array}$ & $\begin{array}{c}1116 \\
\text { vs. } 1198\end{array}$ & $\begin{array}{l}\text { Incidence of } \\
\text { PCR-confirmed, } \\
\text { symptomatic } \\
\text { COVID-19 within } \\
14 \text { days }\end{array}$ & $\begin{array}{l}5.7 \% \text { vs. } 6.2 \% ; \text { RR: } 0.86 ; \\
95 \% \text { CI, } 0.52-1.42\end{array}$ \\
\hline
\end{tabular}

Abbreviations: COVID-19, coronavirus diseases 2019; RR, rate ratio; OR, odds ratio; aOR, adjusted odds ratio; CI, confidence interval; PCR, polymerized chain reaction; SARS-CoV-2, Severe Acute Respiratory Syndrome Coronavirus-2; lt, liter; min, minute.

*All patients received hydroxychloroquine as a part of standard of care. 
proteases [26]. Furthermore, lopinavir/ritonavir had an in vitro inhibitory effect on SARS CoV-1 and MERS-CoV replication [27, 28]. In a phase II open label RCT, the investigators demonstrated that duration of viral shedding was shorter with lopinavir/ritonavir plus ribavirin plus interferon beta- $1 b$ triple combination therapy than the control group consisting of lopinavir/ritonavir plus ribavirin [29].

Table 2 summarizes the results of 4 different RCTs. The WHO SOLIDARITY trial reported similar 28-day mortality rates (10.5\% vs. $10.6 \%$; RR:1.00; 95\% CI, 0.79-1.25; p: 0.97), duration of hospital stay and progression to mechanical ventilation in lopinavir/ritonavir and standard of care groups [13]. A RCT including 199 patients with lopinavir/ritonavir plus standard of care $(n=99)$ vs. standard of care $(n=100)$ found no difference between the two groups in terms of time to clinical improvement and 28-day mortality [30]. The results of RECOVERY trial were consistent with these reports [31]. In another study, there was no significant difference between lopinavir/ritonavir and standard of care arms according to clinical status at 14 days assessed by 7-point ordinal scale of the WHO [32]. Moreover, lopinavir/ritonavir combination therapy did not provide any benefit for normalization of SARS-CoV-2 viral load tested both quantitatively and qualitatively between baseline and day 15 (least square mean difference: $-0.01 ; 95 \%$ CI, -0.05 to 0.03 ; p: 0.67 ).
In the RCT conducted by Cao et al. gastrointestinal side effects were more common in the lopinavir-ritonavir group, but serious adverse events were more frequent in the standard-care group [30]. Moreover, 13 patients (13.8\%) were unable to continue lopinavir/ritonavir up to end of 14-day treatment duration because of adverse events. In the Discovery trial, a significantly higher number of patients experienced at least one severe adverse event in the lopinavir/ritonavir group than in the control group (52.8\% vs. $38.5 \%$; p: 0.02 ) [32].

\section{Remdesivir}

Remdesivir, a prodrug and an adenosine analog, inhibits SARS-CoV-2 replication via binding to the viral RNA-dependent RNA polymerase and premature termination of RNA transcription. Its antiviral efficacy has been demonstrated both in vitro studies and in a rhesus macaque model of SARS-CoV-2 infection [33, 34].

Four RCTs investigated remdesivir for COVID-19 (Table 3). In the WHO SOLIDARITY trial, remdesivir did not differ from the control group regarding 28-day mortality, length of hospital stay, and initiation of mechanical ventilation in the general patient population and in subgroups stratified by study entry ventilation status and glucocorticoid use [13]. The study was criticized that there was a failure to collect the data of mortality completely among some patients discharged from hospital before the end of the study.

Table 2 - Selected randomized controlled trials comparing the efficacy of lopinavir/ritonavir and control group(s).

\begin{tabular}{|c|c|c|c|c|c|}
\hline $\begin{array}{c}\text { Randomized Controlled } \\
\text { Trials }\end{array}$ & $\begin{array}{c}\text { Patient } \\
\text { Characteristics }\end{array}$ & Comparison groups & $\begin{array}{c}\text { Number of patients } \\
\text { included }\end{array}$ & $\begin{array}{l}\text { Primary Outcome } \\
\text { Measure }\end{array}$ & Main results \\
\hline $\begin{array}{l}\text { WHO Solidarity } \\
\text { Trial, Pan et al. [13] }\end{array}$ & $\begin{array}{l}\text { Hospitalized } \\
\text { patients with } \\
\text { COVID-19 }\end{array}$ & $\begin{array}{l}\text { Lopinavir vs. local } \\
\text { standard of care }\end{array}$ & 1399 vs. 1372 & 28-day mortality & $\begin{array}{l}10.5 \% \text { vs. } 10.6 \% \text {; RR: } \\
1.00 ; 95 \% \text { CI, } 0.79- \\
1.25 \text {, p: } 0.97\end{array}$ \\
\hline Cao et al. [30] & $\begin{array}{l}\text { Hospitalized adult } \\
\text { patients with } \\
\text { confirmed SARS- } \\
\text { CoV-2 infection }\end{array}$ & $\begin{array}{l}\text { Lopinavir/ritonavir+ } \\
\text { standard of care vs. } \\
\text { standard of care }\end{array}$ & 99 vs. 100 & $\begin{array}{l}\text { Time to clinical } \\
\text { improvement }\end{array}$ & $\begin{array}{l}\text { HR: } 1.24 ; 95 \% \text { CI, } \\
0.90-1.72\end{array}$ \\
\hline $\begin{array}{l}\text { Recovery } \\
\text { Collaborative Group, } \\
\text { Horby P et al. [31] }\end{array}$ & $\begin{array}{l}\text { Hospitalized } \\
\text { patients with } \\
\text { COVID-19 }\end{array}$ & $\begin{array}{l}\text { Standard of care vs. } \\
\text { lopinavir/ritonavir+ } \\
\text { standard of care }\end{array}$ & 1616 vs. 3424 & 28-day mortality & $\begin{array}{l}22 \% \text { vs. } 23 \% \text {; } \\
\text { RR: } 1.03 ; 95 \% \text { CI, } \\
0.91-1.17 ; \text { p: } 0.60\end{array}$ \\
\hline $\begin{array}{l}\text { Discovery trial, Ader } \\
\text { et al. [32] }\end{array}$ & $\begin{array}{l}\text { Hospitalized } \\
\text { patients with } \\
\text { COVID-19 }\end{array}$ & $\begin{array}{l}\text { Lopinavir/ritonavir+ } \\
\text { standard of care vs. } \\
\text { standard of care }\end{array}$ & 145 vs. 148 & $\begin{array}{l}\text { Clinical status at } 15 \\
\text { days according to } \\
\text { seven-level ordinal } \\
\text { scale }\end{array}$ & $\begin{array}{l}\text { aOR: } 0.83 ; 95 \% \text { CI, } \\
0.55-1.26 ; \text { p: } 0.39\end{array}$ \\
\hline
\end{tabular}

Abbreviations: COVID-19, coronavirus diseases 2019; RR, rate ratio; HR, hazard ratio; aOR, adjusted odds ratio; CI, confidence interval; SARS-CoV-2, Severe Acute Respiratory Syndrome Coronavirus-2. 
Table 3 - Selected randomized controlled trials comparing the efficacy of remdesivir and control group(s).

\begin{tabular}{|c|c|c|c|c|c|}
\hline $\begin{array}{c}\text { Randomized } \\
\text { Controlled Trials }\end{array}$ & Patient Characteristics & Comparison groups & $\begin{array}{l}\text { Number } \\
\text { of patients } \\
\text { included }\end{array}$ & $\begin{array}{c}\text { Primary Outcome } \\
\text { Measure }\end{array}$ & Main results \\
\hline $\begin{array}{l}\text { WHO } \\
\text { Solidarity Trial, } \\
\text { Pan et al. [13] }\end{array}$ & $\begin{array}{l}\text { Hospitalized adult } \\
\text { patients with COVID-19 }\end{array}$ & $\begin{array}{l}\text { Remdesivir vs. local } \\
\text { standard of care }\end{array}$ & $\begin{array}{c}2743 \\
\text { vs. } 2708\end{array}$ & 28-day mortality & $\begin{array}{l}10.9 \% \text { vs. } 11.1 \% \text {; } \\
\text { RR: } 0.95 ; 95 \% \text { CI, } \\
0.81-1.11, \text { p: } 0.50\end{array}$ \\
\hline $\begin{array}{l}\text { ACTT-1 trial, } \\
\text { Beigel et al. [35] }\end{array}$ & $\begin{array}{l}\text { Hospitalized adult } \\
\text { patients with COVID-19 }\end{array}$ & $\begin{array}{l}\text { Remdesivir vs. } \\
\text { placebo }\end{array}$ & $\begin{array}{c}541 \\
\text { vs. } 521\end{array}$ & Time to recovery & $\begin{array}{l}10 \text { vs. } 15 \text { days; } \\
\text { RR: } 1.29 ; 95 \% \text { CI, } \\
1.12-1.49 ; \mathrm{p}:<0.001\end{array}$ \\
\hline $\begin{array}{l}\text { Spinner } \\
\text { et al. [36] }\end{array}$ & $\begin{array}{l}\text { Hospitalized patients } \\
\text { with confirmed } \\
\text { moderate COVID-19 } \\
\text { pneumonia }\end{array}$ & $\begin{array}{l}\text { Standard of care } \\
\text { vs. 5-day course of } \\
\text { remdesivir vs. 10-day } \\
\text { course of remdesivir }\end{array}$ & $\begin{array}{c}200 \\
\text { vs. } 199 \\
\text { vs. } 197\end{array}$ & $\begin{array}{l}\text { Clinical status } \\
\text { on day } 11\end{array}$ & $\begin{array}{l}\text { OR: } 1.65 ; 95 \% \text { CI, } \\
1.09-2.48 ; \mathrm{p}: 0.02\end{array}$ \\
\hline $\begin{array}{l}\text { Goldman } \\
\text { et al. [37] }\end{array}$ & $\begin{array}{l}\text { Hospitalized patients } \\
\text { with confirmed severe } \\
\text { SARS-CoV-2, and } \\
\text { radiologic evidence } \\
\text { of pneumonia }\end{array}$ & $\begin{array}{l}\text { 5-day course of } \\
\text { remdesivir vs. 10-day } \\
\text { course of remdesivir }\end{array}$ & $\begin{array}{c}200 \\
\text { vs. } 197\end{array}$ & $\begin{array}{l}\text { Clinical } \\
\text { improvement of } \\
2 \text { points or more } \\
\text { on the ordinal } \\
\text { scale by day } 14\end{array}$ & $\begin{array}{l}65 \% \text { vs. } 54 \% ;-6.5 \% \text {; } \\
95 \% \text { CI, }-15.7 \text { to } 2.8 \text {; } \\
\text { p: } 0.14\end{array}$ \\
\hline
\end{tabular}

Abbreviations: COVID-19, coronavirus diseases 2019; RR, rate ratio; OR, odds ratio; CI, confidence interval; SARS-CoV-2, Severe Acute Respiratory Syndrome Coronavirus-2.

In ACTT-1, a randomized, double-blind, placebo-controlled trial, the efficacy and safety of intravenous remdesivir were compared with placebo for investigating time to recovery defined by either discharge from the hospital or hospitalization for infection control purposes only among hospitalized COVID-19 patients [35]. The patients treated with remdesivir had a median recovery time of 33\% shorter than those who received placebo (10 days; $95 \%$ confidence interval, 9 to 11 vs. 15 days; $95 \%$ CI, 13 to 18; rate ratio for recovery: $1.29 ; 95 \%$ CI, 1.12-1.49; p: <0.001). Among patients with severe disease, the median time to recovery was 11 days in remdesivir arm and 18 days in placebo arm (RR: 1.31; 95\% CI, 1.12-1.51). However, the median time to recovery was not significantly shorter in remdesivir arm as compared to the placebo arm among patients on mechanical ventilation or ECMO at enrollment (RR: $0.98 ; 95 \%$ CI, $0.70-1.36)$. Furthermore, the estimates of mortality were $11.4 \%$ with remdesivir and $15.2 \%$ with placebo by day 29 (hazard ratio: 0.73; 95\% CI, 0.521.03). Another open label RCT showed that 5-day course of remdesivir treatment was significantly associated with favorable clinical status on day 11 in comparison with standard of care among hospitalized patients with moderate COVID-19 pneumonia (pulmonary infiltrates and room-air oxygen saturation $>94 \%$ ) [36]. However, the same beneficial impact on clinical status could not be shown in those treated with 10-day course of remdesivir (median length of treatment, 6 days). Both of the remdesivir arms (5-day and 10-day) were not significantly different from standard care for any of the exploratory end points (e.g., time to 2-point or greater improvement in clinical status, time to 1-point or greater improvement in clinical status, time to recovery, time to modified recovery, and time to discontinuation of oxygen support). The 28-day all-cause mortality rates were $1 \%$ (95\% CI, 0.0\%-2.6\%; log-rank p: 0.43 vs. standard care) for the 5-day remdesivir group and $2 \%$ (95\% CI, $0.0 \%-3.6 \%$; log-rank p: 0.72 vs. standard care) for the 10-day remdesivir group. The conflicting results reported in this trial can be explained by failure in control for co-interventions such as treatment with dexamethasone or tocilizumab equally in treatment arms and no adjustment for severity of disease. In another open label RCT, there was not a significant difference between a 5-day course and a 10-day course of remdesivir among patients with severe COVID-19 not requiring mechanical ventilation [37]. However, the patients included in 10-day remdesivir arm had more severe disease at study entry and presence of residual confounding factors were still highly likely even with the adjusted analysis.

In the RCT conducted by Spinner et al., the rate 
of adverse events was not statistically significant between the 5-day remdesivir and standard care groups ( $4.8 \%$; $95 \% \mathrm{CI},-5.2 \%$ to $14.7 \%$; p: 0.36$)$, but the difference between the 10-day remdesivir and standard care arms was significant $(12.0 \% ; 95 \%$ CI, 1.6\%-21.8\%; p: 0.02) [36]. In remdesivir receiving patients, nausea, hypokalemia and headache were more common as compared to standard of care. However, severe adverse events tended to be less frequent in both remdesivir groups than standard of care group $(5 \%$ in both vs $9 \%$; difference: $-4.3 \%$; $95 \%$ CI, $-9.7 \%$ to $0.9 \%$; p: 0.11 ). In ACTT-1 trial, severe adverse events were observed in $24.6 \%$ of remdesivir group and $31.6 \%$ of placebo group [35]. Of these adverse events, 41 and 47 events were accepted to be related to remdesivir and to placebo, respectively. Similarly, Goldman et al. reported that nausea $(9 \%$ of patients), worsening respiratory failure $(8 \%)$, elevated alanine aminotransferase level $(7 \%)$, and constipation $(7 \%)$ were the most common adverse reactions [37]. Among all patients, $21 \%$ of those in the 5-day group and 35\% in the 10-day group experienced serious adverse events. The treatment was discontinued due to elevation of aminotransferases in $2.5 \%$ and $3.6 \%$ of patients in the 5-day and 10-day groups, respectively. Remdesivir is not recommended for patients with eGFR $<30$ $\mathrm{mL} /$ minute. Moreover, patients treated with 10day remdesivir had more elevations in creatinine of grade 3 or higher than those receiving 5-day remdesivir. This finding in the 10-day group may have been caused by more severe disease status in that group [37]. Nevertheless, diligent following of hepatic and renal functions would be appropriate among patients who are severely ill. In addition, physicians should be careful in terms of hypersensitivity reactions in patients receiving remdesivir.

\section{Favipiravir}

Favipiravir is a nucleotide analogue that can inhibit the RNA dependent RNA polymerase of several RNA viruses including influenza and coronaviruses [38]. Similarly, it has in vitro inhibitory activity against SARS-CoV-2 [33].

There have been only small-size RCTs with favipiravir in patients with COVID-19 and the results

Table 4 - Selected randomized controlled trials comparing the efficacy of favipiravir and control group(s).

\begin{tabular}{|c|c|c|c|c|c|}
\hline $\begin{array}{c}\text { Randomized } \\
\text { Controlled Trials }\end{array}$ & Patient Characteristics & Comparison groups & $\begin{array}{l}\text { Number } \\
\text { of patients } \\
\text { included }\end{array}$ & $\begin{array}{c}\text { Primary Outcome } \\
\text { Measure }\end{array}$ & Main results \\
\hline Khamis et al. [39] & $\begin{array}{l}\text { Patients hospitalized } \\
\text { with moderate to severe } \\
\text { COVID-19 pneumonia }\end{array}$ & $\begin{array}{l}\text { Favipiravir+ inhaled } \\
\text { interferon beta- } 1 \mathrm{~b} \text { vs. } \\
\text { hydroxychloroquine }\end{array}$ & 44 vs. 45 & $\begin{array}{l}\text { Improvement } \\
\text { of inflammatory } \\
\text { markers, 14-day } \\
\text { mortality, length } \\
\text { of hospital stay }\end{array}$ & $\begin{array}{l}\text { Length of hospital stay, } 7 \text { days } \\
\text { vs. } 7 \text { days; p: } 0.94 ; 14 \text {-day } \\
\text { mortality, } 11.4 \% \text { vs. } 13.3 \% \text {; } \\
\text { p: } 0.77\end{array}$ \\
\hline $\begin{array}{l}\text { Udwadia et al. } \\
\text { [40] }\end{array}$ & $\begin{array}{l}\text { Patients with mild to } \\
\text { moderate confirmed } \\
\text { COVID-19 }\end{array}$ & $\begin{array}{l}\text { Favipiravir+ } \\
\text { standard of care vs. } \\
\text { standard of care }\end{array}$ & 75 vs. 75 & $\begin{array}{l}\text { Time to cessation } \\
\text { of viral shedding }\end{array}$ & $\begin{array}{l}\text { Median, } 5 \text { days; } 95 \% \text { CI, } 4-7 \\
\text { days vs. } 7 \text { days; } 95 \% \text { CI, 5-8 } \\
\text { days; p: } 0.12\end{array}$ \\
\hline Chen et al. [41] & $\begin{array}{l}\text { Patients with COVID-19 } \\
\text { pneumonia }\end{array}$ & $\begin{array}{l}\text { Conventional } \\
\text { therapy+ umifenovir } \\
\text { vs. conventional } \\
\text { therapy+ favipiravir }\end{array}$ & 120 vs. 116 & $\begin{array}{l}\text { Clinical recovery } \\
\text { rate of day } 7\end{array}$ & $\begin{array}{l}61.2 \% \text { vs. } 51.6 \% \text {; difference of } \\
\text { recovery rate: } 0.0954 ; 95 \% \text { CI, } \\
-0.0305 \text { to } 0.2213 ; \text { p: } 0.13\end{array}$ \\
\hline Lou et al. [42] & $\begin{array}{l}\text { Patients with confirmed } \\
\text { COVID-19 }\end{array}$ & $\begin{array}{l}\text { Baloxavir marboxil } \\
\text { vs. favipiravir vs. } \\
\text { control group }\end{array}$ & $\begin{array}{l}10 \text { vs. } \\
9 \text { vs. } 10\end{array}$ & $\begin{array}{l}\text { Percentage of } \\
\text { subjects with viral } \\
\text { negativity by day } \\
14 \text { and the time } \\
\text { from randomization } \\
\text { to clinical } \\
\text { improvement }\end{array}$ & $\begin{array}{l}\text { Percentage of subjects with } \\
\text { viral negativity by day } 14,70 \% \\
\text { vs. } 77 \% \text { vs. } 100 \% \\
\text { The median time from } \\
\text { randomization to clinical } \\
\text { improvement, } 14 \text { days vs. } 14 \\
\text { days vs. } 15 \text { days }\end{array}$ \\
\hline Bosaeed et al. [43] & $\begin{array}{l}\text { Patients hospitalized } \\
\text { with moderate to severe } \\
\text { COVID-19 pneumonia }\end{array}$ & $\begin{array}{l}\text { Favipiravir+ } \\
\text { hydroxychloroquine } \\
\text { vs. standard of care }\end{array}$ & 125 vs. 129 & $\begin{array}{l}\text { Time to clinical } \\
\text { improvement of two } \\
\text { points }\end{array}$ & $\begin{array}{l}\text { Median, } 9 \text { (8-12) days vs. } 7 \\
\text { (6-10) days; hazard ratio: } 0.84 \text {; } \\
95 \% \text { CI, } 0.61-1.15 ; \text { p: } 0.29\end{array}$ \\
\hline
\end{tabular}

Abbreviations: COVID-19, coronavirus diseases 2019; CI, confidence interval; SARS-CoV-2, Severe Acute Respiratory Syndrome Coronavirus-2. 
were inconclusive (Table 4) [39-43]. A recent systematic review did not reveal any significant difference between favipiravir and comparators on fatality rate and mechanical ventilation requirement [44].

\section{Ivermectin}

Ivermectin was shown to have in-vitro activity against SARS-CoV-2 in cell cultures [45]. However, concentrations for antiviral efficacy (IC50) would necessitate administration of considerably higher doses (up to 100-fold) than those classically recommended for use in humans $[46,47]$.

The results of 6 RCTs with ivermectin are shown in Table 5 [48-53]. All of these RCTs had considerable methodological flaws that should be taken into account while evaluating their results. The sample size of all studies was not large enough to reach a statistical power. Majority of these RCTs had open-label design that prevents blinding to the treatment arms. There were several different doses and regimens of ivermectin in these studies. The severity of COVID-19 among the participants and outcome measures of the studies were not generally well defined. In addition, there may be a risk of publication bias, as mostly smallsized and positive trials have been published so far. However, in a very recently published double-blind RCT, the duration of symptoms was found similar between 5-day ivermectin and placebo groups among mild COVID-19 patients [53].

\section{Other investigated antiviral agents}

Although many potential antiviral agents have been investigated so far in RCTs, including darunavir/cobicistat, umifenovir, sofosbuvir/daclatasvir, sofosbuvir/ledipasvir, ribavirin, nitazoxanide, and various interferon-based regimens, these studies

Table 5 - Selected randomized controlled trials comparing the efficacy of ivermectin and control group(s).

\begin{tabular}{|c|c|c|c|c|c|}
\hline $\begin{array}{l}\text { Randomized } \\
\text { Controlled } \\
\text { Trials }\end{array}$ & $\begin{array}{c}\text { Patient } \\
\text { Characteristics }\end{array}$ & Comparison groups & $\begin{array}{c}\text { Number of } \\
\text { patients included }\end{array}$ & $\begin{array}{c}\text { Primary Outcome } \\
\text { Measure }\end{array}$ & Main results \\
\hline $\begin{array}{l}\text { Ahmed } \\
\text { et al. [50] }\end{array}$ & $\begin{array}{l}\text { Laboratory- } \\
\text { confirmed SARS- } \\
\text { CoV-2 infection } \\
\text { with fever, cough, } \\
\text { or sore throat }\end{array}$ & $\begin{array}{l}\text { Ivermectin vs. } \\
\text { ivermectin+ } \\
\text { doxycycline vs. placebo }\end{array}$ & 24 vs. 24 vs. 24 & $\begin{array}{l}\text { Time to virologic } \\
\text { clearance, measured } \\
\text { on days } 3,7 \text {, and } 14 \text {, } \\
\text { then weekly until PCR } \\
\text { result was negative }\end{array}$ & $\begin{array}{l}\text { Shorter mean time to virologic clearance } \\
\text { with ivermectin than placebo; } 9.7 \text { days } \\
\text { vs. } 12.7 \text { days; p: } 0.02 \text {, but not with } \\
\text { ivermectin plus doxycycline; } 11.5 \text { days } \\
\text { vs. } 12.7 \text { days p: } 0.27\end{array}$ \\
\hline $\begin{array}{l}\text { Chachar } \\
\text { et al. [48] }\end{array}$ & $\begin{array}{l}\text { Mild and confirmed } \\
\text { COVID-19 patients }\end{array}$ & Ivermectin vs. control & 25 vs. 25 & $\begin{array}{l}\text { Symptoms reported } \\
\text { on day } 7\end{array}$ & $\begin{array}{l}\text { Proportion of asymptomatic patients at } \\
\text { day } 7 ; 64 \% \text { vs. } 60 \% \text {; p: } 0.50\end{array}$ \\
\hline $\begin{array}{l}\text { Chaccour } \\
\text { et al. [49] }\end{array}$ & $\begin{array}{l}\text { Patients with non- } \\
\text { severe confirmed } \\
\text { COVID-19 }\end{array}$ & Ivermectin vs. placebo & 12 vs. 12 & $\begin{array}{l}\text { Positive SARS-CoV-2 } \\
\text { PCR result from an NP } \\
\text { swab at day } 7 \text { post- } \\
\text { treatment }\end{array}$ & $\begin{array}{l}12 \text { patients }(100 \%) \text { in both groups had a } \\
\text { positive PCR (for gene N), and } 11 \text { of } 12 \\
\text { who received ivermectin }(92 \%) \text { and } 12 \\
\text { of } 12 \text { who received placebo }(100 \%) \text { had a } \\
\text { positive PCR (for gene E); p: } 1.0 \text { for both } \\
\text { comparisons }\end{array}$ \\
\hline $\begin{array}{l}\text { Hashim } \\
\text { et al. [51] }\end{array}$ & $\begin{array}{l}\text { Both outpatient and } \\
\text { inpatient confirmed } \\
\text { COVID-19 patients }\end{array}$ & $\begin{array}{l}\text { Ivermectin plus } \\
\text { doxycycline plus } \\
\text { standard therapy vs. } \\
\text { standard therapy alone }\end{array}$ & 70 vs. 70 & Mean recovery time & Mean, $10.1 \pm 5.3$ vs. $17.9 \pm 6.8 ;$ p: $<0.0001$ \\
\hline $\begin{array}{l}\text { Elgazzar } \\
\text { et al. [52] }\end{array}$ & $\begin{array}{l}\text { Symptomatic } \\
\text { and confirmed } \\
\text { COVID-19 patients }\end{array}$ & $\begin{array}{l}\text { Hydroxychloroquine } \\
\text { (mild to moderate) vs. } \\
\text { hydroxychloroquine } \\
\text { (severe) vs. ivermectin } \\
\text { (mild to moderate) vs. } \\
\text { ivermectin (severe) }\end{array}$ & $\begin{array}{l}100 \text { vs. } 100 \text { vs. } \\
100 \text { vs. } 100\end{array}$ & $\begin{array}{l}\text { Clinical, laboratory } \\
\text { improvement and/or } \\
2 \text { consecutive negative } \\
\text { PCR results } \geq 48 \text { hours } \\
\text { apart }\end{array}$ & $\begin{array}{l}\text { Mild or moderate disease, } 74 \% \text { vs. } 99 \% \text {; } \\
\text { p }<0.001 \text {, } \\
\text { Severe disease, } 50 \% \text { vs. } 94 \% \text {; p: }<0.001\end{array}$ \\
\hline $\begin{array}{l}\text { López- } \\
\text { Medina et } \\
\text { al. [53] }\end{array}$ & $\begin{array}{l}\text { Symptomatic and } \\
\text { confirmed mild } \\
\text { COVID-19 patients }\end{array}$ & Ivermectin vs. placebo & 200 vs. 200 & $\begin{array}{l}\text { Time to resolution } \\
\text { of symptoms within } \\
21 \text { day }\end{array}$ & $\begin{array}{l}10 \text { vs. } 12 \text { days; HR: } 1.07 ; 95 \text { CI, } 0.87-1.32 \text {; } \\
\text { p: } 0.53\end{array}$ \\
\hline
\end{tabular}

Abbreviations: COVID-19, coronavirus diseases 2019; HR; hazard ratio; CI, confidence interval; NP, nasopharyngeal; PCR, polymerized chain reaction; SARS-CoV-2, Severe Acute Respiratory Syndrome Coronavirus-2. 
have serious limitations [29, 54-69]. Until the results of ongoing trials evaluating these agents are available, the use of these drugs for the treatment of COVID-19 should be limited to randomized controlled trials.

\section{IMMUNOMODULATORS}

Glucocorticoids

Considering the uncontrolled inflammatory response during the second phase of COVID-19, steroids, as a potent immunomodulator, deserve to be evaluated to address both acute respiratory distress syndrome and systemic hyperinflammation.

In this section, 5 different RCTs are evaluated and summarized in Table 6. In a randomized, controlled, open-label, adaptive, platform trial (RECOVERY), dexamethasone (6 mg once daily for up to ten days) and usual care alone were compared [70]. Dexamethasone reduced 28-day mortality rate significantly in patients receiving invasive mechanical ventilation $(29.0 \%$ vs.
40.7\%, RR: $0.65 ; 95 \%$ CI, 0.51-0.82; p: <0.001) and in those receiving simple oxygen $(21.5 \%$ vs. 25.0\%; RR: 0.80; 95\% CI, 0.70-0.92; p: 0.002). In contrast, the mortality rates were similar in both patient groups who did not receive respiratory support at randomization $(17.0 \%$ vs. $13.2 \%$, RR: 1.22; 95\% CI, 0.93-1.61; p: 0.14). In addition, use of dexamethasone was associated with a shorter duration of hospitalization and a higher probability of discharge within 28 days (RR: 1.11; 95\% CI, 1.04-1.19; p: 0.002). Among patients not under invasive mechanical ventilation at randomization, the risk of progression to the composite secondary outcome encompassing invasive mechanical ventilation or death was lower among those allocated to dexamethasone (RR: $0.9195 \%$ CI, 0.82-1.00; p: 0.049). In another randomized double-blind sequential trial enrolling patients with COVID-19 related respiratory failure, hydrocortisone was not associated with lower risk of treatment failure (death or persistent respiratory support) at day 21 (42.1\% vs. 50.7\%; difference of proportions: $-8.6 \%$; $95 \% \mathrm{CI},-24.9 \%$ to $7.7 \%$;

Table 6 - Selected randomized controlled trials comparing the efficacy of glucocorticoids and control group(s).

\begin{tabular}{|c|c|c|c|c|c|}
\hline $\begin{array}{l}\text { Randomized } \\
\text { Controlled Trials }\end{array}$ & Patient Characteristics & $\begin{array}{l}\text { Comparison } \\
\text { groups }\end{array}$ & $\begin{array}{l}\text { Number } \\
\text { of patients } \\
\text { included }\end{array}$ & $\begin{array}{l}\text { Primary } \\
\text { Outcome } \\
\text { Measure }\end{array}$ & Main results \\
\hline $\begin{array}{l}\text { Recovery } \\
\text { Collaborative Group, } \\
\text { Horby P et al. [70] }\end{array}$ & $\begin{array}{l}\text { Hospitalized patients with } \\
\text { COVID-19 }\end{array}$ & $\begin{array}{l}\text { Dexamethasone+ } \\
\text { usual care vs. usual } \\
\text { care }\end{array}$ & 2104 vs. 4321 & $\begin{array}{l}\text { 28-day } \\
\text { mortality }\end{array}$ & $\begin{array}{l}21.6 \% \text { vs. } 24.6 \% ; \text { RR: } 0.83 ; \\
95 \% \text { CI, } 0.74-0.92 ; \text { p: }<0.001\end{array}$ \\
\hline $\begin{array}{l}\text { CAPE COVID Trial, } \\
\text { Dequin et al. [71] }\end{array}$ & $\begin{array}{l}\text { Patients admitted to the } \\
\text { intensive care unit for } \\
\text { COVID-19-related acute } \\
\text { respiratory failure }\end{array}$ & $\begin{array}{l}\text { Hydrocortisone vs. } \\
\text { placebo }\end{array}$ & 76 vs. 73 & $\begin{array}{l}\text { Treatment } \\
\text { failure on } \\
\text { day } 21\end{array}$ & $\begin{array}{l}42.1 \% \text { vs. } 50.7 \% \text {; difference } \\
\text { of proportions: }-8.6 \% ; 95 \% \\
\text { CI, }-24.9 \% \text { to } 7.7 \% \text {; }: 0.29\end{array}$ \\
\hline $\begin{array}{l}\text { REMAP-CAP } \\
\text { COVID-19 } \\
\text { Corticosteroid } \\
\text { domain, Angus et } \\
\text { al. [72] }\end{array}$ & $\begin{array}{l}\text { Presumed or confirmed } \\
\text { SARS-CoV-2 infection } \\
\text { who were admitted to } \\
\text { an intensive care unit for } \\
\text { provision of respiratory } \\
\text { or cardiovascular organ } \\
\text { support }\end{array}$ & $\begin{array}{l}\text { Fixed 7-day course } \\
\text { of hydrocortisone } \\
\text { vs. shock-dependent } \\
\text { course vs. no } \\
\text { hydrocortisone }\end{array}$ & $\begin{array}{l}143 \text { vs. } 152 \\
\text { vs. } 108\end{array}$ & $\begin{array}{l}\text { Organ support- } \\
\text { free days } \\
\text { within } 21 \text { days }\end{array}$ & $\begin{array}{l}\text { Bayesian probability of } \\
\text { superiority } 93 \% \text { for fixed- } \\
\text { dose hydrocortisone, } \\
80 \% \text { for shock-dependent } \\
\text { hydrocortisone compared } \\
\text { with no hydrocortisone }\end{array}$ \\
\hline $\begin{array}{l}\text { The CoDEX trial, } \\
\text { Tomazini et al. [73] }\end{array}$ & $\begin{array}{l}\text { Patients with COVID-19 } \\
\text { and moderate to severe } \\
\text { ARDS }\end{array}$ & $\begin{array}{l}\text { Dexamethasone+ } \\
\text { standard of care vs. } \\
\text { standard of care }\end{array}$ & 151 vs. 148 & $\begin{array}{l}\text { Ventilator-free } \\
\text { days during the } \\
\text { first } 28 \text { days }\end{array}$ & $\begin{array}{l}6.6(95 \% \text { CI, } 5.0-8.2) \text { vs. } 4.0 \\
\text { (95\% CI, 2.9-5.4); difference: } \\
\text { 2.6; } 95 \% \text { CI, } 0.2-4.38 \text {; p: } 0.04\end{array}$ \\
\hline $\begin{array}{l}\text { Metcovid trial, } \\
\text { Jeronimo et al. [74] }\end{array}$ & $\begin{array}{l}\text { Adults hospitalized with } \\
\text { suspected COVID-19 and } \\
\text { in use of supplementary } \\
\text { oxygen or under IMV }\end{array}$ & $\begin{array}{l}\text { Methylprednisolone } \\
\text { vs. placebo }\end{array}$ & 194 vs. 199 & $\begin{array}{l}\text { 28-day } \\
\text { mortality }\end{array}$ & $37.1 \%$ vs. $38.2 \% ;$ p: 0.62 \\
\hline
\end{tabular}

Abbreviations: COVID-19, coronavirus diseases 2019; ARDS; acute respiratory distress syndrome; RR, rate ratio; CI, confidence interval; IMV, invasive mechanical ventilation; SARS-CoV-2, Severe Acute Respiratory Syndrome Coronavirus-2. 
p: 0.29) [71]. However, since patient enrollment was arrested early, this trial was likely unpowered to elucidate clinically important differences in the primary outcome. Based on the results of the REMAP-CAP COVID-19 corticosteroid domain open label adaptive RCT, a 7-day fixed-dose course of hydrocortisone treatment $(50 \mathrm{mg}$ or 100 mg every 6 hours) or shock-dependent dosing of hydrocortisone (50 mg every 6 hours when shock was clinically evident) achieved $93 \%$ and $80 \%$ probabilities of superiority as compared to no hydrocortisone regarding the odds of improvement in organ support-free days within 21 days [72]. Tomazini et al carried out an open label RCT comparing dexamethasone plus standard of care and standard of care alone in terms of ventilator-free days as a primary outcome [73]. Since the RECOVERY trial was published before attaining to targeted sample size, this trial was prematurely stopped. Among the enrolled patients $(n=299)$, mean ventilator-free days were $6.6(95 \% \mathrm{CI}, 5.0$ 8.2) and 4.0 (95\% CI, 2.9-5.4) in hydrocortisone and standard of care alone groups, respectively (difference: 2.26; 95\% CI, 0.2-4.38; p: 0.04). In contrast, no significant difference was found between the two groups in any of the prespecified secondary outcomes including all-cause mortality at 28 days, ICU-free days during the first 28 days, mechanical ventilation duration at 28 days, or the 6-point ordinal scale at 15 days. The differences in outcomes between the RECOVERY trial and this study can be explained with some limitations of this trial as following:

i) dexamethasone administration in $35 \%$ of patients allocated in standard of care group,

ii) not reaching to pre-defined statistical power for secondary endpoints because of premature interruption of patient recruitment.

In another placebo-controlled double-blind RCT from Brazil (Metcovid), the short-term use of methylprednisolone was evaluated in clinically, epidemiologically and radiologically suspected COVID-19 patients [74]. The results of this trial demonstrated no reduction in 28-day mortality rate with administration of methylprednisolone. However, in a subgroup analysis, there was an inclination of lower mortality among patients over 60 years old. Since the patients younger than 60 years old had low CRP level and less severe disease, a potential harm was pointed with methylprednisolone in this group. Similarly, in the RECOVERY trial, the patients not receiving supplemental oxygen also had a propensity towards increased mortality when using dexamethasone. In the Metcovid trial, the infection was confirmed among $81.3 \%$ of participants by SARS-CoV-2 RT-PCR and hydrocortisone administration did not affect virus clearance in respiratory secretion until day 7 . In addition, the STOIC (a phase 2, open-label RCT) trial demonstrated the beneficial effect of inhaled budenoside (400 $\mu \mathrm{g}$ twice daily) on emergency room or hospital admission, symptom resolution, and body temperature within 7 days of symptom onset in patients with mild COVID-19. [75]. In a meta-analysis of 7 randomized controlled trials of critically ill COVID-19 patients, administration of systemic corticosteroids was consistently associated with lower 28-day mortality when compared with usual care or placebo (summary OR: 0.66; 95\% CI, 0.53-0.82; p: <0.001) [76].

In these RCTs and meta-analysis, corticosteroid administration was not found to be associated with higher rate of severe side effects, more frequent bacterial or fungal infections, and sepsis or septic shock. However, as compatible with the well-known side effects of glucocorticoids, hyperglycemia and requirement of insulin therapy tended to be higher in corticosteroid receiving arms.

\section{Tocilizumab}

After it is proved that elevated IL-6 levels and ensuing hyperinflammation are crucial harbingers for severe disease, tocilizumab, a monoclonal anti-IL-6-receptor blocking antibody, has been adapted into clinical trials to uncover its efficacy in mitigating COVID-19 associated hyperinflammation [77].

In this section, 8 different RCTs were reviewed and described in Table 7. In the RECOVERY trial, hospitalized COVID-19 patients were included if they had hypoxia (SPO2<92\% on ambient air) and evidence of systemic inflammation (CRP level $\geq 75 \mathrm{mg} / \mathrm{L}$ ) [78]. These patients were randomized to usual standard of care and usual standard of care plus tocilizumab. The primary outcome was 28-day mortality, assessed in intention to treat analysis. In addition, $82 \%$ of the patients $(n=3385)$ were treated with systemic glucocorticoid at randomization. In consequence, the 28-day mortality was significantly lower in tocilizumab arm as compared with usual standard of care alone 
Table 7 - Selected randomized controlled trials comparing the efficacy of tocilizumab and control group(s).

\begin{tabular}{|c|c|c|c|c|c|}
\hline $\begin{array}{l}\text { Randomized } \\
\text { Controlled } \\
\text { Trials }\end{array}$ & Patient Characteristics & Comparison groups & $\begin{array}{l}\text { Number } \\
\text { of patients } \\
\text { included }\end{array}$ & $\begin{array}{c}\text { Primary Outcome } \\
\text { Measure }\end{array}$ & Main results \\
\hline $\begin{array}{l}\text { Recovery } \\
\text { Collaborative } \\
\text { Group, Horby } \\
\text { Pet al. [78] }\end{array}$ & $\begin{array}{l}\text { Hospitalized COVID-19 } \\
\text { patients with hypoxia and } \\
\text { systemic inflammation }\end{array}$ & $\begin{array}{l}\text { Tocilizumab+ usual } \\
\text { standard of care } \\
\text { vs. usual standard } \\
\text { of care }\end{array}$ & $\begin{array}{c}2022 \\
\text { vs. } 2094\end{array}$ & 28-day mortality & $\begin{array}{l}29 \% \text { vs. } 33 \% \text {; RR: } 0.86 ; \\
95 \% \text { CI, } 0.77-0.96 ; \text { p: } 0.007\end{array}$ \\
\hline $\begin{array}{l}\text { REMAP-CAP } \\
\text { Trial, Gordon } \\
\text { et al. [79] }\end{array}$ & $\begin{array}{l}\text { Hospitalized patients with } \\
\text { COVID-19 within } 24 \text { hours of } \\
\text { commencing organ support in } \\
\text { an intensive care unit }\end{array}$ & $\begin{array}{l}\text { Tocilizumab vs. } \\
\text { sarilumab vs. } \\
\text { standard care }\end{array}$ & $\begin{array}{l}353 \text { vs. } 48 \\
\text { vs. } 402\end{array}$ & $\begin{array}{l}\text { Ordinal scale } \\
\text { combining in- } \\
\text { hospital mortality } \\
\text { and days free of } \\
\text { organ support to } \\
\text { day } 21\end{array}$ & $\begin{array}{l}\text { Median organ support free } \\
\text { days, } 10 \text { (IQR: }-1 \text { to } 16 \text { ) vs. } \\
11 \text { (IQR: }-1 \text { to } 16 \text { ) vs. } 0 \text { (IQR: } \\
-1 \text { to } 15) \text {; median adjusted } \\
\text { OR: } 1.64 ; 95 \% \text { credible } \\
\text { intervals [CrI], } 1.25-2.14 \text { for } \\
\text { tocilizumab and } 1.76 ; 95 \% \text { CrI, } \\
\text { 1.17-2.91 for sarilumab }\end{array}$ \\
\hline $\begin{array}{l}\text { Hermine } \\
\text { et al. [80] }\end{array}$ & $\begin{array}{l}\text { Patients with COVID-19 and } \\
\text { moderate or severe pneumonia } \\
\text { requiring at least } 3 \mathrm{~L} / \text { min of } \\
\text { oxygen but without ventilation } \\
\text { or admission to the intensive } \\
\text { care unit }\end{array}$ & $\begin{array}{l}\text { Tocilizumab+ usual } \\
\text { care vs. usual care }\end{array}$ & 64 vs. 67 & $\begin{array}{l}\text { Scores higher than } \\
5 \text { on the World } \\
\text { Health Organization } \\
\text { 10-point clinical } \\
\text { progression scale on } \\
\text { day } 4 \text { and survival } \\
\text { without need of } \\
\text { ventilation (including } \\
\text { noninvasive } \\
\text { ventilation) at day } 14\end{array}$ & $\begin{array}{l}\text { Median posterior absolute } \\
\text { risk difference: }-9.0 \% \text {; } \\
90 \% \text { credible interval, }-21.0 \\
\text { to 3.1, with a posterior } \\
\text { probability of negative } \\
\text { ARD of } 89.0 \% \\
24 \% \text { vs. } 36 \% \text {, median } \\
\text { posterior HR, } 0.58 ; 90 \% \\
\text { credible intervals, } 0.33-1.00\end{array}$ \\
\hline $\begin{array}{l}\text { Salvarani } \\
\text { et al. [81] }\end{array}$ & $\begin{array}{l}\text { Patients with COVID- } 19 \\
\text { pneumonia documented by } \\
\text { radiologic imaging, partial } \\
\text { pressure of arterial oxygen to } \\
\text { fraction of inspired oxygen } \\
\text { ratio between } 200 \text { and } 300 \\
\mathrm{~mm} \mathrm{Hg} \text {, and an inflammatory } \\
\text { phenotype defined by fever and } \\
\text { elevated C-reactive protein }\end{array}$ & $\begin{array}{l}\text { Tocilizumab vs. } \\
\text { control }\end{array}$ & 60 vs. 63 & $\begin{array}{l}\text { Entry into the } \\
\text { intensive care } \\
\text { unit with invasive } \\
\text { mechanical } \\
\text { ventilation, death } \\
\text { from all causes, or } \\
\text { clinical aggravation }\end{array}$ & $\begin{array}{l}28.3 \% \text { vs. } 27.0 \% \text {; RR: } 1.05 ; \\
95 \% \text { CI, } 0.59-1.86\end{array}$ \\
\hline $\begin{array}{l}\text { EMPACTA } \\
\text { trial Salama } \\
\text { et al. [84] }\end{array}$ & $\begin{array}{l}\text { Patients hospitalized with } \\
\text { COVID-19 pneumonia who } \\
\text { were not receiving mechanical } \\
\text { ventilation }\end{array}$ & $\begin{array}{l}\text { Tocilizumab vs. } \\
\text { placebo }\end{array}$ & $\begin{array}{c}249 \\
\text { vs. } 128\end{array}$ & $\begin{array}{l}\text { Mechanical } \\
\text { ventilation or death } \\
\text { by day } 28 .\end{array}$ & $\begin{array}{l}12.0 \% \text { vs. } 19.3 \% ; \text { HR: } 0.56 \text {; } \\
95 \% \text { CI, } 0.33-0.97 \text {; p: } 0.04\end{array}$ \\
\hline $\begin{array}{l}\text { Stone } \\
\text { et al. [82] }\end{array}$ & $\begin{array}{l}\text { Patients with laboratory } \\
\text { confirmed COVID-19 } \\
\text { hyperinflammatory states, and } \\
\text { at least two of the following } \\
\text { signs: fever (body temperature } \\
>38^{\circ} \mathrm{C} \text { ), pulmonary infiltrates, } \\
\text { or the need for supplemental } \\
\text { oxygen }\end{array}$ & $\begin{array}{l}\text { Tocilizumab vs. } \\
\text { placebo }\end{array}$ & 161 vs. 82 & $\begin{array}{l}\text { Intubation or death, } \\
\text { assessed in a time-to- } \\
\text { event analysis }\end{array}$ & HR: $0.83 ; 0.38-1.81 ; \mathrm{p}: 0.64$ \\
\hline $\begin{array}{l}\text { Rosas } \\
\text { et al. [85] }\end{array}$ & $\begin{array}{l}\text { Patients hospitalized with } \\
\text { severe COVID-19 pneumonia }\end{array}$ & $\begin{array}{l}\text { Tocilizumab vs. } \\
\text { placebo }\end{array}$ & $\begin{array}{c}294 \\
\text { vs. } 144\end{array}$ & $\begin{array}{l}\text { Clinical status on a } \\
7 \text {-category ordinal } \\
\text { scale at day } 28\end{array}$ & $\begin{array}{l}1.0(1.0 \text { to } 1.0) \text { vs. } 2.0 \\
\text { (1.0 to } 4.0) \text {; OR: } 1.19 ; 95 \% \text { CI, } \\
\text { 0.81-1.76; p: } 0.36\end{array}$ \\
\hline $\begin{array}{l}\text { Veiga } \\
\text { et al. [83] }\end{array}$ & $\begin{array}{l}\text { Patients hospitalized with } \\
\text { severe or critical COVID-19 } \\
\text { pneumonia }\end{array}$ & $\begin{array}{l}\text { Tocilizumab+ } \\
\text { standard of care vs. } \\
\text { standard of care }\end{array}$ & 65 vs. 64 & $\begin{array}{l}\text { A composite of } \\
\text { death or mechanical } \\
\text { ventilation at } 15 \text { days }\end{array}$ & $\begin{array}{l}28 \% \text { vs. } 20.0 \% \text {; OR: } 1.54 \\
95 \% \text { CI, } 0.66-3.66 ; \text { p: } 0.32\end{array}$ \\
\hline
\end{tabular}

Abbreviations: COVID-19, coronavirus diseases 2019; RR, rate ratio; OR, odds ratio; HR, hazard ratio; CI, confidence interval; PCR, polymerized chain reaction; SARS-CoV-2, Severe Acute Respiratory Syndrome Coronavirus-2; ARD, absolute risk difference; L, liter; min, minute. 
arm (29\% vs. $33 \%$; RR: 0.86; $95 \%$ CI, 0.77-0.96; p: 0.007). Among patients allocated to tocilizumab arm, there were significantly higher number of patients discharged from hospital alive within 28 days (54\% vs. $47 \%$; RR: 1.22; 95\% CI, 1.12-1.34; p: $<0.0001)$. Similarly, patients receiving tocilizumab were less likely to reach the composite end point consisting of mechanical ventilation or death $(33 \%$ vs. $38 \%$; RR: 0.85 ; 95\% CI, 0.78-0.93; p: 0.0005). Therefore, it was reported that tocilizumab was associated with a significantly better outcomes regardless of level of respiratory support among hypoxic COVID-19 patients with evidence of systemic inflammation. Intriguingly, a remarkable benefit was observed particularly in patients receiving concomitant systemic corticosteroid. In the REMAP-CAP trial, hospitalized COVID-19 patients were randomized to tocilizumab, sarilumab and standard care treatment arms within 24 hours of starting organ support [79]. As a result, IL-6 receptor antagonists improved organ support-free days and survival in patients requiring organ support and treated in an intensive care unit. Furthermore, both IL-6 receptor antagonists were effective across all pre-defined secondary outcomes such as 90-day survival, hospital discharge, improvement in the WHO 7-point ordinal scale at day 14.

Besides of the RECOVERY and the REMAP-CAP trials, other RCTs published to date were inconclusive [80-83]. The EMPACTA trial showed that patients receiving tocilizumab were less likely to progress to mechanical ventilation or death by day 28 (hazard ratio: 0.56; 95\% CI, 0.32-0.97) [84]. In contrast, there was no difference in all-cause mortality (risk difference: $2.0 \%$; $95 \% \mathrm{CI},-5.2 \%$ to $7.8 \%$ ). The COVACTA trial reported no difference in clinical status or mortality at day 28 , although the time to hospital discharge was shorter in tocilizumab arm (hazard ratio: 1.35; 95\%CI, 1.021.79) [85]. Moreover, in another RCT, two different regimens of sarilumab (400 $\mathrm{mg}$ and $200 \mathrm{mg}$ ) were found to be inefficient in COVID-19 patients receiving supplemental oxygen [86]. However, adequately powered trials are now crucial to appreciate whether alternative IL-6 antagonists to tocilizumab are effective particularly for reducing mortality.

The conflicting results obtained from RCTs published to date can be originated from the fact that both the RECOVERY and the REMAP CAP trials commenced treatment early (at median of two days of hospitalization in RECOVERY; $<24$ hours in the ICU for REMAP-CAP), suggesting early initiation of tocilizumab may maximize effectiveness in patients with early rapidly progressive disease. When all data from these 8 trials were analyzed together, allocation to tocilizumab was associated with a $13 \%$ proportional reduction in 28 -day mortality (death rate ratio: $0.87 ; 95 \% \mathrm{CI}, 0.79-0.96$; p: 0.005) [78]. Similarly, a large-scale meta-analysis indicated higher chance of survival when tocilizumab is added to standard care (log odds ratio: $-0.41 ; 95 \%$ CI, -0.68 to -0.14 ; p: <0.001) [87]. Moreover, in another meta-analysis, combination of systemic corticosteroids with tocilizumab was reported be associated with lower rate of mortality (RR: $0.58 ; 95 \%$ CI, 0.42-0.91; I': 75\%) [88].

The frequencies of serious side effects among patients receiving tocilizumab were similar to those not receiving tocilizumab (RR: 0.89 ; $95 \%$ CI, $0.74-$ 1.07) [8]. Tocilizumab has been notoriously associated with gastrointestinal perforations and case reports of bowel perforations were recently reported with the use of tocilizumab for COVID-19 patients [89]. Additionally, increased risks of infection may be aggravated by the combination of glucocorticoids and tocilizumab [90].

\section{Baricitinib}

Janus kinase (JAK) inhibitors act by preventing phosphorylation of signal transduction proteins that stimulate immune activation and inflammation emerged as a cellular response to proinflammatory cytokines [91]. Furthermore, baricitinib has a potential antiviral activity through blocking viral endocytosis and viral entrance into susceptible cells [92].

There were only two RCTs in the literature. In the Adaptive COVID-19 Treatment Trial 2 (ACTT-2) in which patients were randomized to remdesivir plus baricitinib (4 mg/day up to 14 days or discharge) vs. remdesivir alone [93]. In this trial, patients receiving baricitinib had a shorter time to recovery as compared with control (median, 7 days vs. 8 days; rate ratio for recovery: 1.16 ; $95 \%$ CI, 1.01-1.32; p: 0.03), and a 30\% higher probability of improvement in clinical status at day 15 (odds ratio: $1.3 ; 95 \% \mathrm{CI}, 1.0-1.6)$. These beneficial effects were more prominent in patients supported by high-flow oxygen or non-invasive mechanical ventilation at enrollment. There was also a trend 
towards a lower rate of mortality in remdesivir plus baricitinib group (4.7\% vs. $7.1 \%$; rate ratio: $0.65 ; 95 \%$ CI, 0.39-1.09). Additionally, baricitinib plus remdesivir combination were more likely to be associated with clinical recovery at day 28 (69.3\% vs. $59.7 \%$; rate ratio: $1.29 ; 95 \%$ CI, $1.00-$ 1.66). Likewise, patients receiving combination therapy were less likely to progress to mechanical ventilation or ECMO through day $29(10 \%$ vs. 15.2\%; RR: 0.66; 95\% CI, 0.46-0.93). In COV-BARRIER, phase 3, double-blind, randomized, placebo-controlled trial, baricitinib was found to be associated with significant improvement in both 28day all-cause mortality (8.1\% vs. $13.1 \%$; HR:0.57; 95\% CI, 0.41-0.78; p: 0.0018) and 60-day all-cause mortality (10.3\% vs. $15.2 \%$; HR:0.62; 95\% CI, 0.47 0.83; p:0.0050) among hospitalized COVID-19 patients [94]. In contrast, the primary composite outcome defined as progression to high-flow oxygen, non-invasive ventilation, mechanical ventilation, or death was similar in comparison groups $(27.8 \%$ vs. $30.5 \%$; OR:0.85; 95\% CI, 0.67-1.08; p:0.18). This study is the first trial assessing the benefit/risk of baricitinib when added to standard of care therapy primarily including corticosteroids (mostly dexamethasone). A very recent double-blind placebo-controlled trial showed that tofacitinib (another oral JAK inhibitor) led to a lower cumulative incidence of death or respiratory failure through day 28 than placebo (risk ratio, $0.63 ; 95 \%$ CI, 0.41-0.97; p: 0.04) [95].

In ACTT-2 trial, patients receiving combination therapy had a lower rate of any serious adverse events through day 28 (16\% vs. $21 \%$; RR: 0.76 ; $95 \%$ CI, 0.59-0.99). In addition, the risk of new infections was lower in the combination group compared with remdesivir alone. However, patients who received concomitant glucocorticoids experienced serious or non-serious infectious episodes more frequently as compared with those did not receive glucocorticoids. However, serious adverse events, serious infections and venous thromboembolic events were seen with similar frequencies in barictinib and placebo arms of COV-BARRIER trial. As baricitinib has been routinely used for the treatment of rheumatoid arthritis, it has some well-known side effects including upper respiratory tract infections, opportunistic infections, thrombosis, cytopenia, abnormalities in liver function tests, elevations in creatinine phosphokinase, and increases in lipids [96].

\section{IL-1 inhibitors}

Currently, there are 2 available IL- 1 inhibitors (anakinra and canakinumab) being used for the treatment of rheumatoid arthritis in adults. In order to tame uncontrolled inflammatory response of COVID-19, IL-1 inhibitors have been tested in 4 RCTs to date. Caricchio et al. assessed the efficacy of canakinumab for severe COVID-19 patients not requiring invasive mechanical ventilation and having elevated CRP or ferritin level [97]. The survival without invasive mechanical ventilation from day 3 to day 29 was similar between canakinumab and placebo arms (88.8\% vs. $85.7 \%$; $95 \%$ CI, $-3.1 \%$ to $9.3 \%$ ). Similarly, canakinumab did not confer any mortality benefit when compared with placebo $(4.9 \%$ vs. $7.2 \%$; $95 \% \mathrm{CI},-6.7 \%$ to $2.2 \%)$. In another RCT, the efficacy of anakinra was assessed in mild-to-moderate COVID-19 patients with an excess of inflammation (CRP $>25 \mathrm{mg} / \mathrm{L})$ and increased IL-1 concentration. This study was interrupted prematurely due to its futility and showed no benefit of anakinra in preventing progression to mechanical ventilation and death [98]. In contrast to these studies, SAVE-MORE trial indicated favorable clinical outcomes in anakinra-treated patients [99]. Among these patients, the WHO ordinal clinical progression scale and mortality were significantly lower compared to placebo group (OR 0.36; 95\%CI 0.26-0.50; $\mathrm{P}<0.001$ and $6.9 \%$ vs. $3.2 \%$; HR: 0.45 ; p: 0.045 , respectively). Finally, in the REMAP-CAP adaptive platform trial, anakinra was ineffective at improving survival and reducing duration of organ support among critically ill COVID-19 patients treated in ICU [100].

\section{CONCLUSIONS}

Based on available data, usage of HQ and lopinavir/ritonavir has already been abandoned. Dexamethasone $6 \mathrm{mg}$ IV or PO for 10 days (or until discharge) can be regarded as standard of care for the treatment of severe and critical illnesses. Further studies are required to inform the generalizability of treatment with different glucocorticoids for patients with COVID-19. Baricitinib and remdesivir can be considered as an option in the treatment of patients who cannot receive dexamethasone and require high-flow oxygen or non-invasive mechanical ventilation at enrollment. Additionally, baricitinib can be suggested in combination with 
dexamethasone with or without remdesivir in severe and critical COVID-19 patients. Remdesivir can be suggested for hospitalized severe COVID-19 patients. The duration of therapy should be 5 days rather than 10 days. Administration of remdesivir appears to be ineffective in critically ill patients who are mechanically ventilated and receiving ECMO. It should not be wielded for outpatients or hospitalized non-severe COVID-19 cases. Tocilizumab can be suggested in hospitalized severe or critical COVID-19 patients with evidence of hyperinflammatory state. It's essential to initiate tocilizumab early during the hyperinflammatory phase. For other IL-6 inhibitors such as sarilumab, we need to see the results of large-scale RCTs. Among other treatment options including ivermectin, and favipiravir and IL-1 inhibitors, existing evidence is not enough to recommend these therapies outside the context of a clinical trial.

\section{Conflict of interest}

All authors have no conflict of interest to be stated.

\section{Funding}

None.

\section{REFERENCES}

[1] Johns Hopkins University of Medicine. COVID-19 Dashboard by the Center for Systems Science and Engineering (CSSE) at Johns Hopkins University. 2021. Available at: https://coronavirus.jhu.edu/map.html [accessed 03 Agu 2021].

[2] Wu Z, McGoogan JM. Wu Z, McGoogan JM. Characteristics of and important lessons from the Coronavirus Disease 2019 (COVID-19) Outbreak in China: Summary of a Report of 72314 Cases From the Chinese Center for Disease Control and Prevention. JAMA. 2020; 323 (13), 1239-42.

[3] Cai Q, Chen F, Wang T, et al. Obesity and COVID-19 severity in a designated hospital in Shenzhen, China. Diabetes Care. 2020; 43 (7), 1392-98.

[4] Garg S, Kim L, Whitaker M, et al. Hospitalization rates and characteristics of patients hospitalized with laboratory-confirmed coronavirus disease 2019 - COVIDNET, 14 states, March 1-30, 2020. MMWR Morb Mortal Wkly Rep. 2020; 69 (15), 458-64.

[5] Guan WJ, Ni ZY, Hu Y, et al. Clinical characteristics of coronavirus disease 2019 in China. N Engl J Med. 2020; 382 (18), 1708-20.

[6] Wu C, Chen X, Cai Y, et al. Risk factors associated with acute respiratory distress syndrome and death in patients with coronavirus disease 2019 pneumonia in
Wuhan, China. JAMA Intern Med. 2020; 180 (7), 934-43. [7] Palaiodimos L, Kokkinidis DG, Li W, et al. Severe obesity, increasing age and male sex are independently associated with worse in-hospital outcomes, and higher in-hospital mortality, in a cohort of patients with COVID-19 in the Bronx, New York. Metabolism. 2020; $108,154262$.

[8] Bhimraj A, Morgan RL, Shumaker AH, et al. Infectious Diseases Society of America Guidelines on the Treatment and Management of Patients with COVID-19. 2021. Available at: https://www.idsociety.org/globalassets/idsa/practice-guidelines/covid-19/treatment/ idsa-covid-19-gl-tx-and-mgmt-v4.0.0.pdf [accessed 14 April 2021].

[9] National Institutes of Health. COVID-19 Treatment Guidelines Panel. Coronavirus Disease 2019 (COVID-19) Treatment Guidelines. 2021. Available at: https: / / files.covid19treatmentguidelines.nih.gov/ guidelines/covid19treatmentguidelines.pdf [accessed 21 April 2021].

[10] Liu J, Cao R, Xu M, et al. Hydroxychloroquine, a less toxic derivative of chloroquine, is effective in inhibiting SARS-CoV-2 infection in vitro. Cell Discov. 2020; 6, 16.

[11] Maisonnasse P, Guedj J, Contreras V, et al. Hydroxychloroquine use against SARS-CoV-2 infection in non-human primates. Nature. 2020; 585 (7826), 584-87.

[12] RECOVERY Collaborative Group, Horby P, Mafham M, Linsell L, et al. Effect of Hydroxychloroquine in Hospitalized Patients with Covid-19. N Engl J Med. 2020; 383 (21), 2030-40.

[13] WHO Solidarity Trial Consortium, Pan H, Peto R, Henao-Restrepo AM, et al. Repurposed Antiviral Drugs for Covid-19 - Interim WHO Solidarity Trial Results. N Engl J Med. 2021; 384 (6), 497-11.

[14] Cavalcanti AB, Zampieri FG, Rosa RG, et al. Hydroxychloroquine with or without Azithromycin in Mild-to-Moderate Covid-19. N Engl J Med. 2020; 383 (21), 2041-52.

[15] Self WH, Semler MW, Leither LM, et al. Effect of Hydroxychloroquine on Clinical Status at 14 Days in Hospitalized Patients With COVID-19. JAMA. 2020; 324 (21), 2165-76.

[16] Tang W, Cao Z, Han M, et al. Hydroxychloroquine in patients with mainly mild to moderate coronavirus disease 2019: open label, randomised controlled trial. BMJ. 2020; 369, m1849.

[17] Furtado RHM, Berwanger O, Fonseca HA, et al. Azithromycin in addition to standard of care versus standard of care alone in the treatment of patients admitted to the hospital with severe COVID-19 in Brazil (COALITION II): a randomised clinical trial. Lancet. 2020; 396 (10256), 959-67.

[18] Boulware DR, Pullen MF, Bangdiwala AS, et al. A Randomized Trial of Hydroxychloroquine as postexposure prophylaxis for Covid-19. N Engl J Med. 2020; 383 (6), 517-25. 
[19] Abella BS, Jolkovsky EL, Biney BT, et al. Efficacy and safety of Hydroxychloroquine vs Placebo for Pre-exposure SARS-CoV-2 Prophylaxis among Health Care Workers. JAMA Intern Med. 2021; 181 (2), 195-02.

[20] Mitjà O, Corbacho-Monné M, Ubals M, et al. A Cluster-Randomized Trial of Hydroxychloroquine for Prevention of Covid-19. N Engl J Med. 2021; 384 (5), 41727.

[21] Youngster I, Arcavi L, Schechmaster R, et al. Medications and glucose-6-phosphate dehydrogenase deficiency: an evidence-based review. Drug Saf. 2010; 33 (9), 713-26.

[22] Mohammad S, Clowse MEB, Eudy AM, CriscioneSchreiber LG. Examination of Hydroxychloroquine Use and Hemolytic Anemia in G6PDH-Deficient Patients. Arthritis Care Res (Hoboken). 2018; 70 (3), 481-85.

[23] Rainsford KD, Parke AL, Clifford-Rashotte M, Kean WF. Therapy and pharmacological properties of hydroxychloroquine and chloroquine in treatment of systemic lupus erythematosus, rheumatoid arthritis and related diseases. Inflammopharmacology. 2015; 23 (5), 231-69.

[24] Fiolet T, Guihur A, Rebeaud ME, Mulot M, Peiffer-Smadja N, Mahamat-Saleh Y. Effect of hydroxychloroquine with or without azithromycin on the mortality of coronavirus disease 2019 (COVID-19) patients: a systematic review and meta-analysis. Clin Microbiol Infect. 2021; 27 (1), 19-27.

[25] Ghazy RM, Almaghraby A, Shaaban R, et al. A systematic review and meta-analysis on chloroquine and hydroxychloroquine as monotherapy or combined with azithromycin in COVID-19 treatment. Sci Rep. 2020; 10 (1), 22139.

[26] Zumla A, Chan JF, Azhar EI, Hui DS, Yuen KY. Coronaviruses-drug discovery and therapeutic options. Nat Rev Drug Discov. 2016; 15 (5), 327-47.

[27] Chen F, Chan KH, Jiang Y, et al. In vitro susceptibility of 10 clinical isolates of SARS coronavirus to selected antiviral compounds. J Clin Virol 2004; 31(1), 69-75.

[28] Wu CY, Jan JT, Ma SH, et al. Small molecules targeting severe acute respiratory syndrome human coronavirus. Proc Natl Acad Sci USA. 2004; 101 (27), 10012-17.

[29] Hung IF, Lung KC, Tso EY, et al. Triple combination of interferon beta- $1 \mathrm{~b}$, lopinavir- ritonavir, and ribavirin in the treatment of patients admitted to hospital with COVID-19: an open-label, randomised, phase 2 trial. Lancet. 2020; 395 (10238), 1695-04.

[30] Cao B, Wang Y, Wen D, et al. A Trial of LopinavirRitonavir in Adults Hospitalized with Severe Covid-19. N Engl J Med. 2020; 382 (19), 1787-99.

[31] RECOVERY Collaborative Group. Lopinavir-ritonavir in patients admitted to hospital with COVID-19 (RECOVERY): a randomised, controlled, open-label, platform trial. Lancet. 2020; 396 (10259), 1345-52.

[32] Ader F, Peiffer-Smadja N, Poissy J, et al. Antiviral drugs in hospitalized patients with COVID- 19-the DisCoVeRy trial. medRvix. 2021. doi, 10.1101/ 2021.01.08.20248149.

[33] Wang M, Cao R, Zhang L, et al. Remdesivir and chloroquine effectively inhibit the recently emerged novel coronavirus (2019-nCoV) in vitro. Cell Res. 2020; 30 (3), 269-71.

[34] Williamson BN, Feldmann F, Schwarz B, et al. Clinical benefit of remdesivir in rhesus macaques infected with SARS-CoV-2. Nature. 2020; 585 (7824), 273-76.

[35] Beigel JH, Tomashek KM, Dodd LE, et al. Remdesivir for the Treatment of Covid-19 - Final Report. N Engl J Med. 2020; 383 (19), 1813-26.

[36] Spinner CD, Gottlieb RL, Criner GJ, et al. Effect of Remdesivir vs Standard Care on Clinical Status at 11 Days in Patients With Moderate COVID-19. JAMA. 2020; 324 (11), 1048-57.

[37] Goldman JD, Lye DCB, Hui DS, et al. Remdesivir for 5 or 10 Days in Patients with Severe Covid-19. N Engl J Med. 2020; 383 (19), 1827-37.

[38] Furuta Y, Gowen BB, Takahashi K, Shiraki K, Smee DF, Barnard DL. Favipiravir (T-705), a novel viral RNA polymerase inhibitor. Antiviral Res. 2013; 100 (2), 446-54. [39] Khamis F, Al Naabi H, Al Lawati A, et al. Randomized controlled open label trial on the use of favipiravir combined with inhaled interferon beta- $1 \mathrm{~b}$ in hospitalized patients with moderate to severe COVID-19 pneumonia. Int J Infect Dis. 2021; 102, 538-43.

[40] Udwadia ZF, Singh P, Barkate H, et al. Efficacy and safety of favipiravir, an oral RNA-dependent RNA polymerase inhibitor, in mild-to-moderate COVID-19: A randomized, comparative, open-label, multicenter, phase 3 clinical trial. Int J Infect Dis. 2021; 103, 62-71.

[41] Chen C, Zhang Y, Huang J, et al. Favipiravir versus Arbidol for COVID-19: A Randomized Clinical Trial. medRvix. 2020. doi, 10.1101/2020.03.17.20037432.

[42] Lou Y, Liu L, Yao H, et al. Clinical Outcomes and Plasma Concentrations of Baloxavir Marboxil and Favipiravir in COVID-19 Patients: An Exploratory Randomized, Controlled Trial. medRvix. 2020; doi, 10.1101/2020.04.29.20085761.

[43] Bosaeed M, Mahmoud E, Alharbi A, et al. Favipiravir and Hydroxychloroquine Combination Therapy in Patients with Moderate to Severe COVID-19 (FACCT Trial): An Open-Label, Multicenter, Randomized, Controlled Trial. Infect Dis Ther. 2021; 28, 1-17.

[44] Özlüşen B, Kozan Ş, Akcan RE, et al. Effectiveness of favipiravir in COVID-19: a live systematic review. Eur J Clin Microbiol Infect Dis. 2021; 1-9.

[45] Caly L, Druce JD, Catton MG, Jans DA, Wagstaff KM. The FDA-approved drug ivermectin inhibits the replication of SARS-CoV-2 in vitro. Antiviral Res. 2020; 178, 104787.

[46] Chaccour C, Hammann F, Ramón-García S, Rabinovich NR. Ivermectin and COVID-19: keeping rigor in times of urgency. Am J Trop Med Hyg. 2020; 102 (6), 1156-57. 
[47] Guzzo CA, Furtek CI, Porras AG, et al. Safety, tolerability, and pharmacokinetics of escalating high doses of ivermectin in healthy adult subjects. J Clin Pharmacol. 2002; 42 (10), 1122-33.

[48] Chachar AZK, Khan KA, Asif M, Tanveer K, Khaqan A, Basri R. Effectiveness of ivermectin in SARSCOV-2/COVID-19 Patients. Int J of Sci. 2020; 9 (9), 31-35. [49] Chaccour C, Casellas A, Blanco-Di Matteo A, et al. The effect of early treatment with ivermectin on viral load, symptoms and humoral response in patients with non-severe COVID-19: A pilot, double-blind, placebo-controlled, randomized clinical trial. EClinicalMedicine. 2021; 32, 100720.

[50] Ahmed S, Karim MM, Ross AG, et al. A five-day course of ivermectin for the treatment of COVID-19 may reduce the duration of illness. Int J Infect Dis. 2021; 103, 214-16.

[51] Hashim HA, Maulood MF, Rasheed AW, et al. Controlled randomized clinical trial on using ivermectin with doxycycline for treating COVID-19 patients in Baghdad, Iraq. medRxiv. 2020; doi, 10.1101/2020.10.26.20219345.

[52] Elgazzar A, Hany B, Youssef SA, Hafez M, Moussa $\mathrm{H}$, Eltaweel A. Efficacy and safety of ivermectin for treatment and prophylaxis of COVID-19 pandemic. Research Square. 2020; doi, 10.21203/rs.3.rs-100956/v2.

[53] López-Medina E, López P, Hurtado IC, et al. Effect of Ivermectin on time to resolution of symptoms among adults with mild COVID-19: a randomized clinical trial. JAMA. 2021; 325 (14), 1426-35.

[54] Chen J, Xia L, Liu L, et al. Antiviral Activity and Safety of Darunavir/Cobicistat for the Treatment of COVID-19. Open Forum Infect Dis. 2020; 7 (7), ofaa241.

[55] Nojomi M, Yassin Z, Keyvani H, et al. Effect of Arbidol (Umifenovir) on COVID-19: a randomized controlled trial. BMC Infect Dis. 2020; 20 (1), 954.

[56] Li Y, Xie Z, Lin W, et al. An exploratory randomized controlled study on the efficacy and safety of lopinavir/ritonavir or arbidol treating adult patients hospitalized with mild/moderate COVID-19 (ELACOI). medRvix. 2020; doi, 10.1101/2020.03.19.20038984.

[57] Kasgari HA, Moradi S, Shabani AM, et al. Evaluation of the efficacy of sofosbuvir plus daclatasvir in combination with ribavirin for hospitalized COVID-19 patients with moderate disease compared with standard care: a single-centre, randomized controlled trial. J Antimicrob Chemother. 2020; 75 (11), 3373-78.

[58] Roozbeh F, Saeedi M, Alizadeh-Navaei R, et al. Sofosbuvir and daclatasvir for the treatment of COVID-19 outpatients: a double-blind, randomized controlled trial. J Antimicrob Chemother. 2021; 76 (3), 753-57.

[59] Sadeghi A, Ali Asgari A, Norouzi A, et al. Sofosbuvir and daclatasvir compared with standard of care in the treatment of patients admitted to hospital with moderate or severe coronavirus infection (COVID-19): a randomized controlled trial. J Antimicrob Chemother. 2020; 75 (11), 3379-85.
[60] Abdel-Salam Elgohary M, Hasan EM, Ibrahim AA, et al. Efficacy of Sofosbuvir plus Ledipasvir in Egyptian patients with COVID-19 compared to standard treatment: Randomized controlled trial. medRvix. 2021; doi, 10.1101/2021.05.19.21257429.

[61] Khalili H, Nourian A, Ahmadinejad Z, et al. Efficacy and safety of sofosbuvir/ ledipasvir in treatment of patients with COVID-19; A randomized clinical trial. Acta Biomed. 2020; 91 (4), e2020102.

[62] Singh BO, Moirangthem B, Panda PK, et al. Safety and efficacy of antiviral therapy alone or in combination in COVID-19 - a randomized controlled trial (SEV COVID Trial). medRvix. 2021; doi, 10.1101/2021.06.06.21258091.

[63] Rocco PRM, Silva PL, Cruz FF, et al. Early use of nitazoxanide in mild COVID-19 disease: randomised, placebo-controlled trial. Eur Respir J. 2021; 58 (1), 2003725.

[64] Silva M, Espejo A, Pereyra ML, et al. Efficacy of Nitazoxanide in reducing the viral load in COVID-19 patients: Randomized, placebo-controlled, single-blinded, parallel-group, pilot study. medRvix. 2021; doi, 10.1101/2021.03.03.21252509.

[65] Davoudi-Monfared E, Rahmani H, Khalili H, et al. Efficacy and safety of interferon -1a in treatment of severe COVID-19: A randomized clinical trial. Antimicrob Agents Chemother. 2020; 64 (9), e01061-20.

[66] Alavi Darazam I, Shokouhi S, Pourhoseingholi MA, et al. Role of interferon therapy in severe COVID-19: the COVIFERON randomized controlled trial. Sci Rep. 2021; 11 (1), 8059.

[67] Feld JJ, Kandel C, Biondi MJ, et al. Peginterferon lambda for the treatment of outpatients with COVID-19: a phase 2, placebo-controlled randomised trial. Lancet Respir Med. 2021; 9 (5), 498-10.

[68] Jagannathan P, Andrews JR, Bonilla H, et al. Peginterferon Lambda-1a for treatment of outpatients with uncomplicated COVID-19: a randomized placebo-controlled trial. Nat Commun. 2021; 12 (1), 1967.

[69] Monk PD, Marsden RJ, Tear VJ, et al. Safety and efficacy of inhaled nebulised interferon beta-1a (SNG001) for treatment of SARS-CoV-2 infection: a randomised, double-blind, placebo-controlled, phase 2 trial. Lancet Respir Med. 2021; 9(2), 196-206.

[70] RECOVERY Collaborative Group, Horby P, Lim WS, Emberson JR, et al. Dexamethasone in Hospitalized Patients with Covid-19. N Engl J Med. 2021; 384 (8), 693-04.

[71] Dequin PF, Heming N, Meziani F, et al. Effect of Hydrocortisone on 21-Day Mortality or Respiratory Support Among Critically Ill Patients With COVID-19. JAMA. 2020; 324 (13), 1298-06.

[72] Angus DC, Derde L, Al-Beidh F, et al. Effect of Hydrocortisone on Mortality and Organ Support in Patients With Severe COVID-19. JAMA. 2020; 324 (13), 1317-29.

[73] Tomazini BM, Maia IS, Cavalcanti AB, et al. Effect of Dexamethasone on Days Alive and Ventilator-Free 
in Patients With Moderate or Severe Acute Respiratory Distress Syndrome and COVID-19. JAMA. 2020; 324 (13), 1307-16.

[74] Jeronimo CMP, Farias MEL, Val FFA, et al. Methylprednisolone as Adjunctive Therapy for Patients Hospitalized With COVID-19 (Metcovid): A Randomised, Double-Blind, Phase IIb, Placebo-Controlled Trial. Clin Infect Dis. 2021; 72 (9), 373-81.

[75] Ramakrishnan S, Nicolau DV Jr, Langford B, et al. Inhaled budesonide in the treatment of early COVID-19 (STOIC): a phase 2, open-label, randomized controlled trial. Lancet Respir Med. 2021; 9 (7), 763-72.

[76] WHO Rapid Evidence Appraisal for COVID-19 Therapies (REACT) Working Group, Sterne JAC, Murthy S, Diaz JV, et al. Association between administration of systemic corticosteroids and mortality among critically ill patients with COVID-19. A meta-analysis. JAMA. 2020; 324 (13), 1330-41.

[77] Chen G, Wu D, Guo W, et al. Clinical and immunological features of severe and moderate coronavirus disease 2019. J Clin Invest. 2020; 130 (5), 2620-29.

[78] RECOVERY Collaborative Group. Tocilizumab in patients admitted to hospital with COVID-19 (RECOVERY): a randomised, controlled, open-label, platform trial. Lancet. 2021; 397 (10285), 1637-45.

[79] REMAP-CAP Investigators, Gordon AC, Mouncey PR, Al-Beidh F, et al. Interleukin-6 Receptor Antagonists in Critically Ill Patients with Covid-19. N Engl J Med. 2021; 384 (16), 1491-02.

[80] Hermine O, Mariette X, Tharaux PL, Resche-Rigon M, Porcher R, Ravaud P. CORIMUNO-19 Collaborative Group. Effect of Tocilizumab vs usual care in adults hospitalized with COVID-19 and moderate or severe pneumonia. JAMA Intern Med. 2021; 181 (1), 32-40.

[81] Salvarani C, Dolci G, Massari M, et al. Effect of Tocilizumab vs standard care on clinical worsening in patients hospitalized with COVID-19 pneumonia. JAMA Intern Med. 2021; 181 (1), 24-31.

[82] Stone JH, Frigault MJ, Serling-Boyd NJ, et al. Efficacy of Tocilizumab in patients hospitalized with Covid-19. N Engl J Med. 2020; 383 (24), 2333-44.

[83] Veiga VC, Prats JAGG, Farias DLC, et al. Effect of tocilizumab on clinical outcomes at 15 days in patients with severe or critical coronavirus disease 2019: randomised controlled trial. BMJ. 2021; 372, 84.

[84] Salama C, Han J, Yau L, et al. Tocilizumab in patients hospitalized with Covid-19 pneumonia. $N$ Engl J Med. 2021; 384 (1), 20-30.

[85] Rosas IO, Bräu N, Waters M, et al. Tocilizumab in hospitalized patients with severe COVID-19 pneumonia. N Engl J Med. 2021; 384 (16), 1503-16.

[86] Lescure FX, Honda H, Fowler RA, et al. Sarilumab in patients admitted to hospital with severe or critical COVID-19: a randomised, double-blind, placebo-controlled, phase 3 trial. Lancet Respir Med. 2021; 9 (5), 522-32.
[87] Conti V, Corbi G, Sellitto C, et al. Effect of Tocilizumab in reducing the mortality rate in COVID-19 patients: a systematic review with meta-Analysis. J Pers Med. 2021; 11, 628.

[88] Alkofide H, Almohaizeie A, Almuhaini S, et al. Tocilizumab and systemic corticosteroids in the management of COVID-19 patients: a systematic review and meta-analysis. Int J Infect Dis. 2021; 14 (21), 00578-6.

[89] Rojo M, Cano-Valderrama O, Picazo S, et al. Gastrointestinal perforation after treatment with Tocilizumab: an unexpected consequence of COVID-19 pandemic. Am Surg. 2020; 86 (6), 565-66.

[90] Guaraldi G, Meschiari M, Cozzi-Lepri A, et al. Tocilizumab in patients with severe COVID- 19: a retrospective cohort study. Lancet Rheumatol. 2020; 2 (8), 474-84.

[91] Zhang W, Zhao Y, Zhang F, et al. The use of anti-inflammatory drugs in the treatment of people with severe coronavirus disease 2019 (COVID-19): the perspectives of clinical immunologists from China. Clin Immunol. 2020; 214, 108393.

[92] Stebbing J, Phelan A, Griffin I, et al. COVID-19: combining antiviral and anti-inflammatory treatments. Lancet Infect Dis. 2020; 20 (4), 400-02.

[93] Kalil AC, Patterson TF, Mehta AK, et al. Baricitinib plus Remdesivir for Hospitalized Adults with Covid-19. N Engl J Med. 2021; 384 (9), 795-07.

[94] Marconi VC, Ramanan AV, de Bono S, et al. Baricitinib plus Standard of Care for Hospitalized Adults with COVID-19. medRxiv. 2021; doi, 10.1101/ 2021.04.30.21255934.

[95] Guimarães PO, Quirk D, Furtado RH, et al. Tofacitinib in Patients Hospitalized with Covid-19 Pneumonia. N Engl J Med. 2021; 385 (5), 406-15.

[96] Jorgensen SCJ, Tse CLY, Burry L, Dresser LD. Baricitinib: A Review of Pharmacology, Safety, and Emerging Clinical Experience in COVID-19. Pharmacotherapy. 2020; 40 (8), 843-56.

[97] Caricchio R, Abbate A, Gordeev I, et al. Effect of Canakinumab vs placebo on survival without invasive mechanical ventilation in patients hospitalized with severe COVID-19: A randomized clinical trial. JAMA. 202; 326 (3), 230-39.

[98] The CORIMUNO-19 Collaborative Group. Effect of anakinra versus usual care in adults in hospital with COVID-19 and mild-to-moderate pneumonia (CORIMUNO-ANA-1): a randomized controlled trial. Lancet Respir Med. 2021; 9 (3), 295-04.

[99] Kyriazopoulou E, Poulakou G, Milionis H, et al. Early Anakinra Treatment for COVID-19 Guided by Urokinase Plasminogen Receptor. medRvix. 2021; doi, 10.1101/2021.05.16.21257283.

[100] The REMAP-CAP Investigators. Effectiveness of Tocilizumab, Sarilumab, and Anakinra for critically ill patients with COVID-19. medRvix. 2021; doi, 10.1101/2021.06.18.21259133. 